\title{
Explaining the Systemic Risk Model Using the Marginal Expected Shortfall Approach (MES) for the Banks Listed on the Tehran Stock Exchange
}

\author{
Kourosh Asayesh ${ }^{1}$ \\ Mirfeiz Fallahshams ${ }^{2}$ \\ Hossein Jahangirnia ${ }^{3}$ \\ Reza Gholami Jamkarani ${ }^{4}$
}

\author{
korosh.asayesh@qodsiau.ac.ir \\ mir.fallahshams@iauctb.ac.ir \\ hosein jahangirnia@qom-iau.ac.ir \\ gholami@qom-iau.ac.ir
}

\begin{abstract}
The purpose of this study is to explain the Systemic Risk Model with Marginal Expected Shortfall Approach (MES) as regards the banks listed on the Tehran Stock Exchange. The research population includes 15 banks that were present in Tehran Stock Exchange or Iran's Over-The-Counter (OTC) for the period 2013 to 2018. Data analysis showed that according to the MES criterion, systemic risk has been declining in the period under review. However, the developments of this index can be divided into two sub-periods 2013-2015 and 2016-2018. In the first period (2013-2015), the level of systemic risk based on this criterion was significantly higher than the level of systemic risk in the second period (2016-2018); Nonetheless, over the time, in the second sub-period, on average, the values amounted to about half of what they were in the first-period level.
\end{abstract}

Keywords: Risk, Systemic Risk, Marginal Expected Shortfall, Financial Crisis, Value at Risk.

JEL Classification: G21، G32، G33.

\footnotetext{
1. Ph.D. Student, Department of Financial Management, Qom Branch, Islamic Azad University, Qom, Iran

2. Associate Professor, Department of Financial Management, Central Tehran Branch, Islamic Azad University, Tehran, Iran (Corresponding Author).

3. Assistant Professor, Department of Accounting, Qom Branch, Islamic Azad University, Qom, Iran.

4. Assistant Professor, Department of Accounting, Qom Branch, Islamic Azad University, Qom, Iran.
} 


\section{تبيين مدل ريسك سيستميك با استفاده از معيار

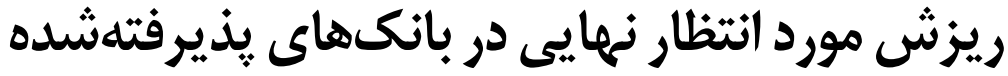 در بورس اوراق بهرادار تهران}

korosh.asayesh@qodsiąu.ac.ir

كوروش آسايث

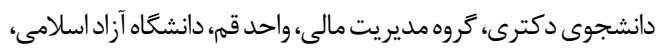

قمه ايران.

mir.fallahshams@iauctb.ac.ir

ميرفيض فلاح شمس ائ

دانشيار كروه مديريت مالى، واحد تهرئ ماندان مركزى، دانشكاه آزاد

اسلامى، تهران، ايران (نويسنده مسئول).

hosein_jahangirnia@qom-iau.ac.ir

حسين جهانغيرنيا

استاديار كروه حسابدارى، واحد قم، دانشعاه آزاد اسلامى، قه، ايران.

gholami@qom-iau.ac.ir

رضا غلامى جمكر انى إنى

استاديار كروه حسابدارى، واحد قم، دانشعاه آزاد اسلامى، قم، ايران.

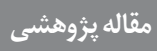

:ذيرش:

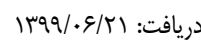

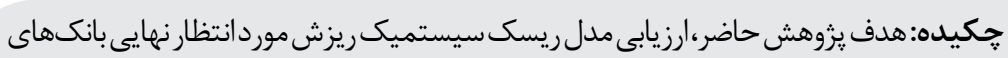

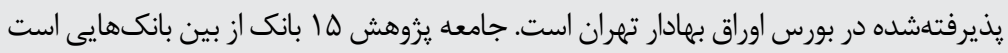

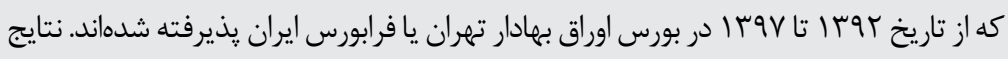

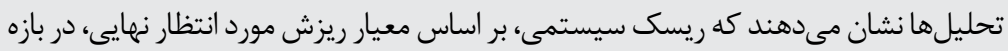

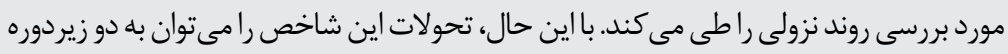

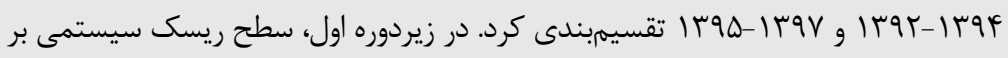

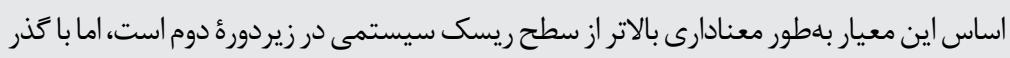

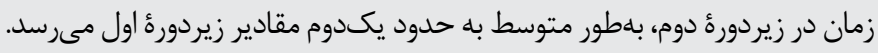

كليدوازهها: ريسك، ريسك سيستمى، ريزش مورد انتظار نهايى، بحران مالى، ارزش در طبقدبندى G21، G32، G33 :JEL. 


\section{مقدمه}

هر جند ظهور اقتصاد كلان جديد با تاكيد بر اهميت نقش بازارهاى مالى از جمله بازار سهام همراه

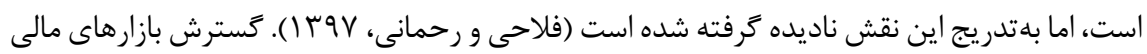
و ايجاد بازارهاى مالى نوين در سطوح مختلف و اقشار جوامع باعث مىشود كه توجه به بورس اوراق بهادار كسترش يابد، بهطورى كه امروزه ميزان مشاركت عموم مردم در بازار سرمايه بلهروشنى مشاهئ ماهده

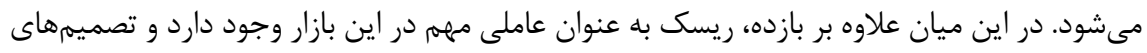

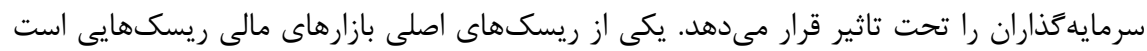

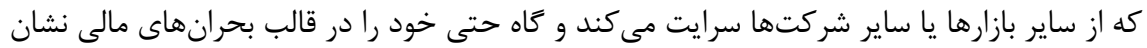

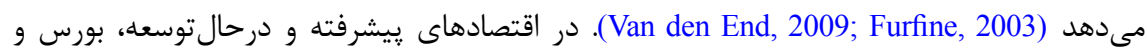
بازار اوراق بهادار به عنوان يكى از اركان سلامت اقتصادى شناخته مىشود (Flannery et al., 2017)،

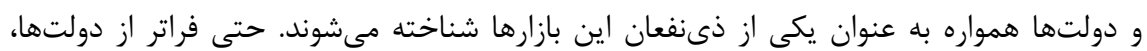
در جوامع بينالمللى و بازارهاى بزرگ سهام در دنيا، تاثير بازار سهامها بر يكديگر مشهود است بـ

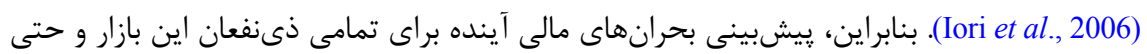

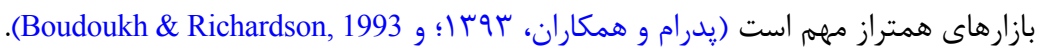

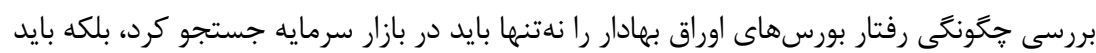

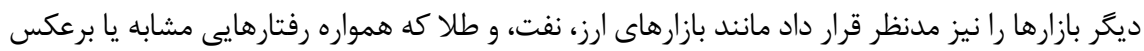

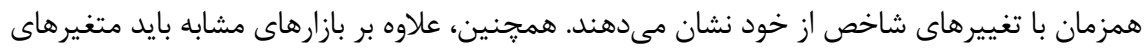

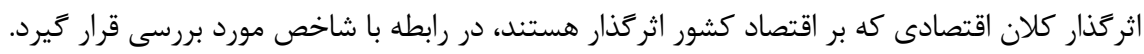

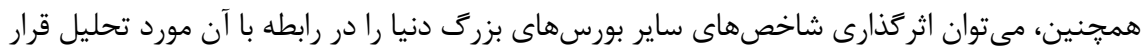

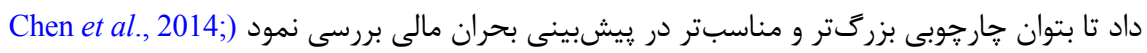

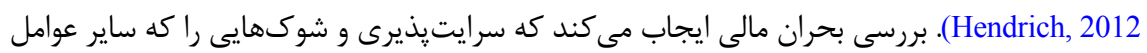

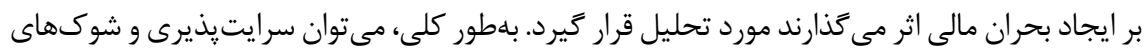

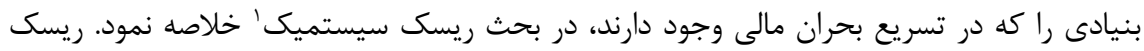

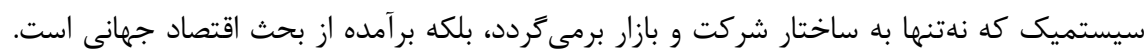

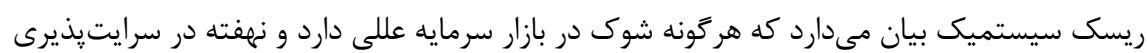
است كه از سوى ساير عوامل اثركذار ناشى مىشود (Guerra et al., 2016). بهطور خلاصه بايد عنوان 
داشت كه ريسك سيستميك بهَّونهاى از عوامل درونى و بيرونى تشكيل شده است كه بايد در راستاى

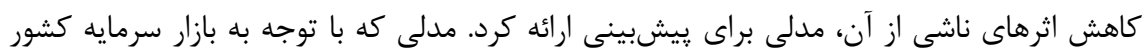

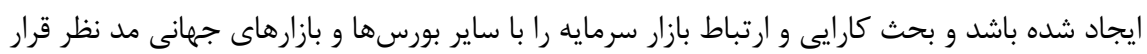

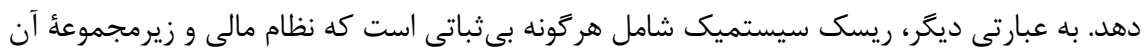
را تهديد مى كند (Billio et al., 2012). بحرانهاى مالى اخير جهان، بهويزه سال ^ • • ז، سياستخذاران و يروهشكران را بر آن داشت كه با صرف تمركز بيشتر به شناخت يديده، زمان وقوع، و شدت اين مهرئ

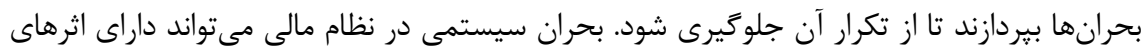

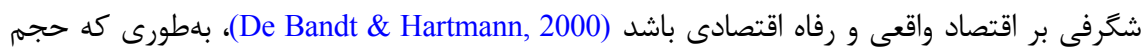
تجارت، سرمايه گذارى خارجى، و رشد اقتصادى را در بسيارى از كشورها با كاهش قابل ملاحظهاى روبهرو كند. اين بحران عامل ورشكستكى برخى از نهادهاى اصلى در كشورهاى مختلف است و مشخصه بارز آن انتقال نوسانها از يك بخش به بخش ديكر است. در اين شرايط، كشور ايران به دليل اينكه بِيوند

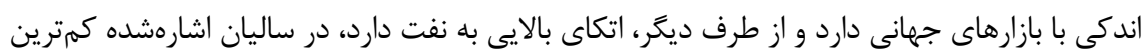

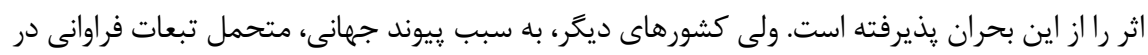

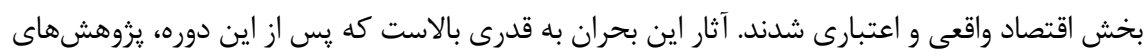

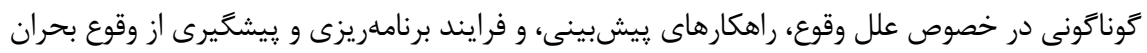

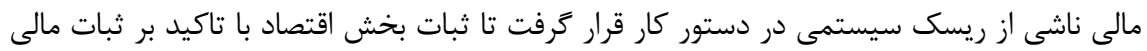
حاصل شود (Laeven et al., 2016). بخش مورد توجهى از منابع مالى در ايران توسط بانكها تخصيص پيدا مىكند (مدنىزاده

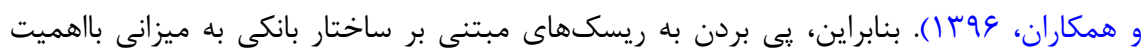

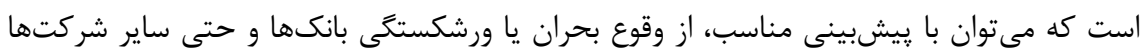
جلوكيرى شود. شايد بتوان كفت حال خوب بانك مىتواند به اقتصاد يوياتر كمك كند و در نهايت به عنوان عاملى موثر بر رشد اقتصادى ظاهر شود. يُ لازم است ريسك سيستمى و سرايتيذيرى

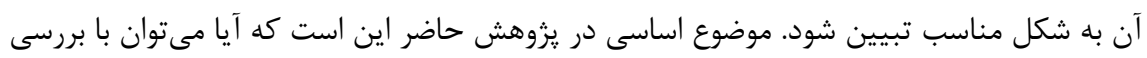

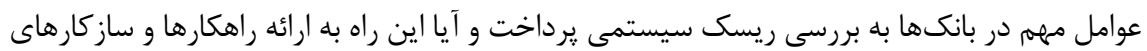

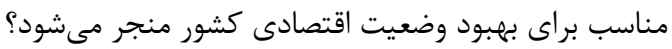




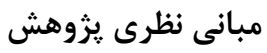

ريسك سيستميك

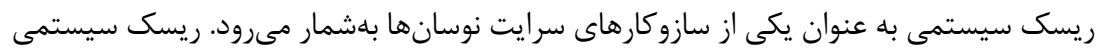

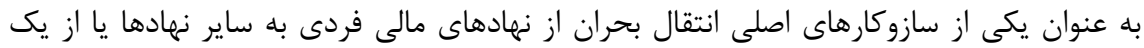

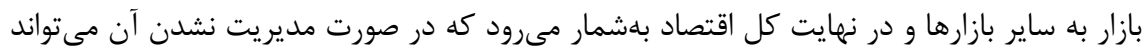

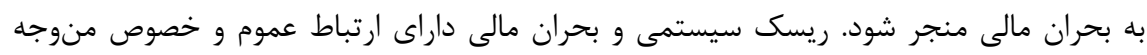

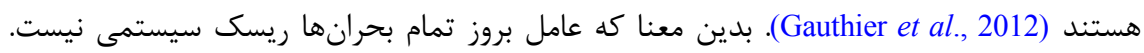

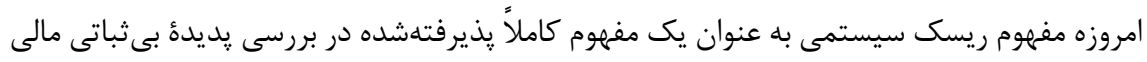

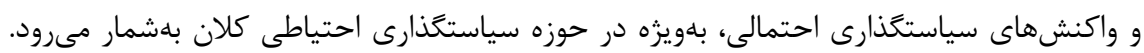

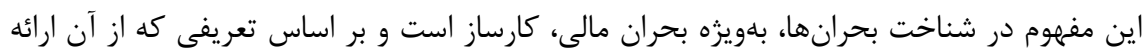

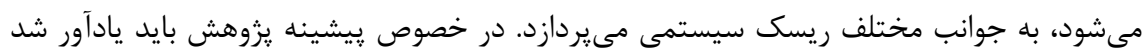

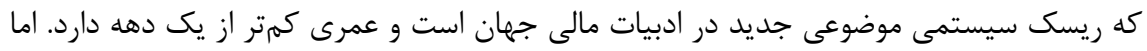

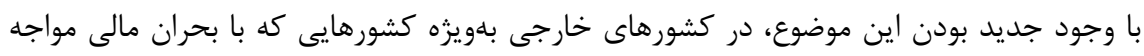

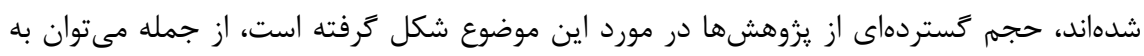

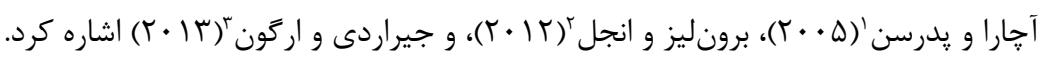

\section{بحران مالى}

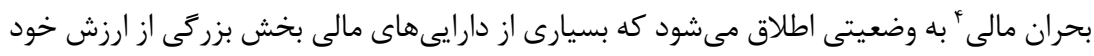

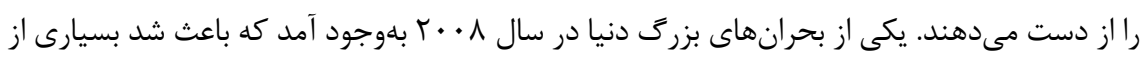

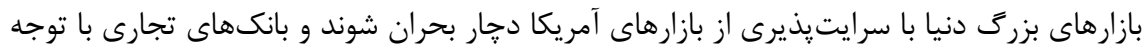

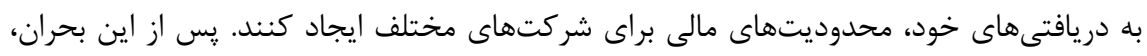
ئروهشها بهطور مستمر به تحليل بحران و سرايتيذيرى آن مى يردازئن (Zubair et al., 2020).

1. Acharya \& Pedersen

2. Brownlees \& Engle

3. Girardi \& Ergün

4. Financial Crisis 


\section{معيار ريزش مورد انتظار نهايى}

معيار ريزش مورد انتظار نهايى (MES)' با عنوان زيان مورد انتظار حاشيهاى كه مشتقشده از مورد زيان مورد انتظار (ES) است، ريسك سيستمى را به صورت بازدهى مورد انتظار سهام يكى موسسه مالى انفرادى، هنگامى كه بازار مالى در شرايط بحرانى قرار دارد، تعريف مى كند. ES در واقع نشاندهنده متوسط زيان در شرايط بحرانى است. يعنى برخلاف VaR كه بيشترين زيان را در شرايط عادى بيان مى كند، ES با فرض اين كه موسسه يا بانك در شرايط بحرانى قرار دارد، متوسط زيان را در حالت بحرانى اندازه مى گيرد. بنابراين، معيار ريزش مورد انتظار نهايى با مشروط كردن شرايط به بحرانى

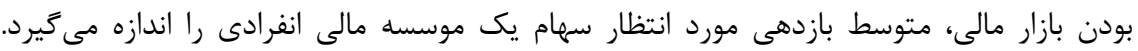

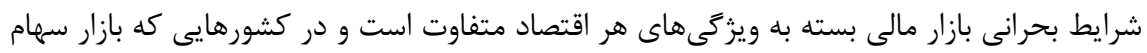

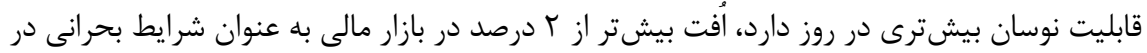

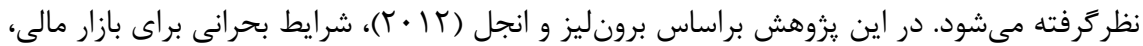
افت بيشتر از † درصد را در شاخص كل بازار بورس اوراق بهادار در نظر ميى كيرد.

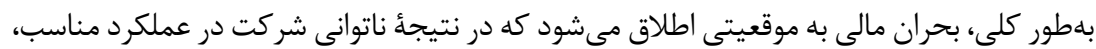
وضعيت شركت بهشدت با كاهش ارزش مواجه مىشود. اين تعريف، طيف گستردهاى از بحرانهاى يِيشآمده در متغيرهاى مالى را در بر مى گيرد. بحران مالى مى تواند ناشى از ايجاد اخلال در يكى از

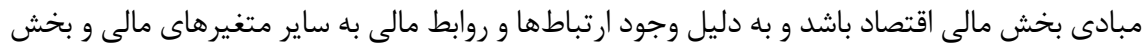
واقعى اقتصاد سرايت نمايد (Iori et al., 2006). بحران بازار سهام، تراز يرداختها، ورشكستكى بانكها و شركتهاى بيمه، تغييرهاى شديد نرخ ارز، و كاهش ارزش يول رايج يك كشور اخلال خودكامبخش

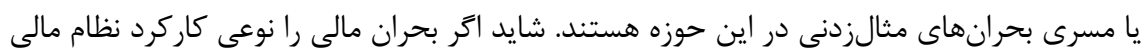

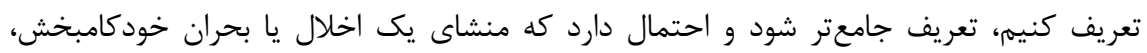
ضعف در مبانى اقتصادى كشور باشد. ريسك سيستميك يكى از موضوعهاى جذاب و مورد علاقه براى قانونكذاران، تصميمَيران، و يروهشكران دانشخاهى است زيرا تبعات بحرانهاى مالى به شكل

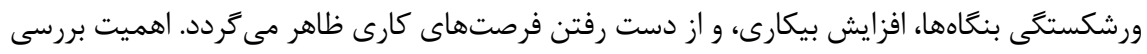
اثرهاى سيستميك در زمينه تنظيم مقررات در بُعد كلان و تصميمگيران در حوزه مديريت ريسك ركى بسيار يرواضح است. شاخصهاى مختلفى براى اندازگگيرى ريسك سيستميك توسط يزوهشگران 
بكار رفته است. ين و همكاران' ( (Y ·r)، ريسك سيستميك را در بازارهاى سهام بينالمللى با نقش

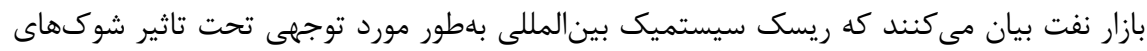
قيمت نفت قرار دارد. علاوه بر اين، يِيشبينى ريسك سيستميك بر اساس بازار نفت در طول دورههاى بازگشت مثبت (يا منفى) نفت و دورههاى نوسان بازار بالا (يا كم) در افقهاى طولانىمدت قوى است.

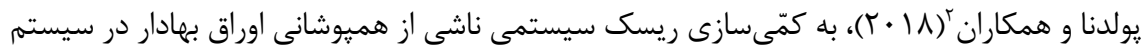

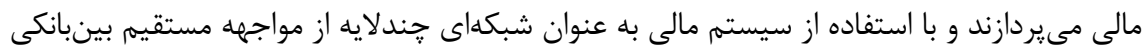

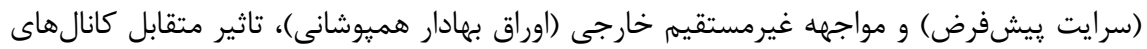

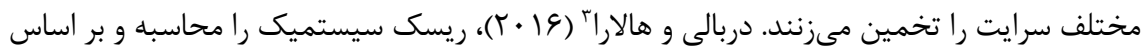

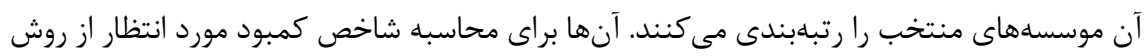

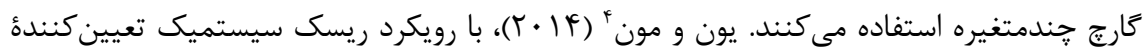
شاخصهاى ريسك سيستميك را نيز مشخص و در انتها مقدار آستانهاى را براى مقدار شاخص تعيين رونين

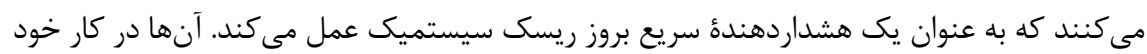

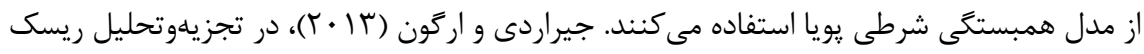
سيستمى در نهادهاى مالى از مدل همبستكى شرطى يويا استفاده مى كنند كه در نهايت ريسك

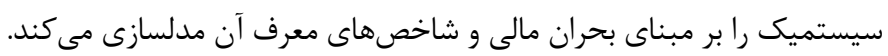

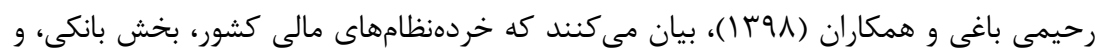
بيمه بلهترتيب بيشترين و كمترين ميزان ريسك سيستمى را دارند. علاوه بر اين، مشخص مىشود كه ميزان ارتباط سيستمى بين موسسههاى مالى متعلق به هر كدام از خردهنظامهاى مالى كشور

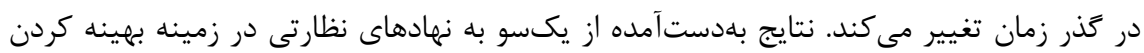

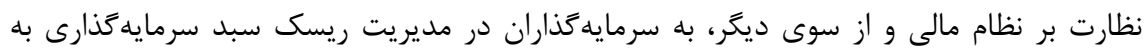
شيوهاى كارامد كمك مى كند. مهدوى كليشمى و همكاران (9 (1))، به ارزيابى ريسك سيستمى در شبكه بانكى ايران با استفاده از معيار تغييرهاى ارزش در معرض ريسك شرطى ميى يردازند. يافتههاى

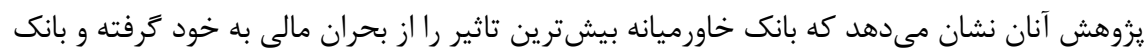

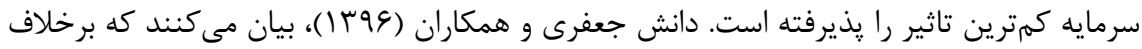

1. Yin et al.

2. Poledna et al.

3. Derbali \& Hallara

4. Yun \& Moon 
يروهش هاى خارجى، بانكها در بروز ريسك سيستمى در ايران نقش تعيين كنندهاى ندارند. حسينى و رضوى ( سوس ()، به بررسى نقش سرمايه در موسسههاى مالى و ريسك سيستمى مى يردازند. در اين يزوهش تخمين ريسك سيستمى به روش كمبود مورد انتظار سيستمى صورت مى گيرد. نتايج اين يروهش نشان مى دهد كه موسسههاى مالى از نظر تاثير بر ريسك سيستمى تفاوتهاى معنادارى با

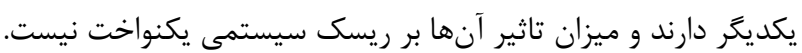

\section{روششناسى يزوهش}

يزوهش حاضر به دليل اين كه به ارائه مدل با استفاده از ساير مدلهاى حاضر مىيردازد و در

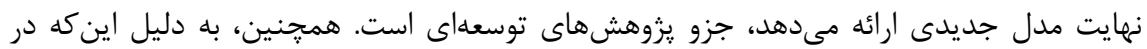
بورس اوراق بهادار تهران مورد بررسى قرار مى

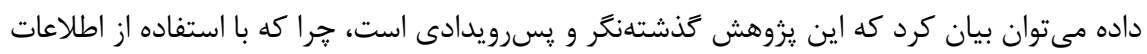

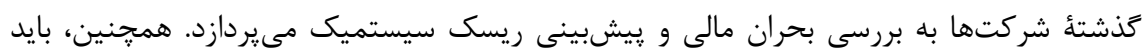

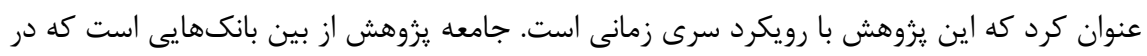

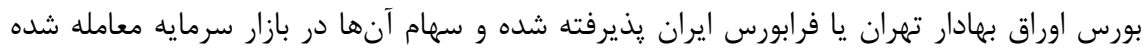
است، كه با توجه به نبود تواتر دادهاى كافى و مناسب براى برخى از بانكهاى نوريا، بانكهايى به به عنوان

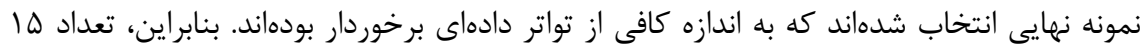

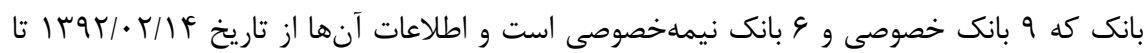

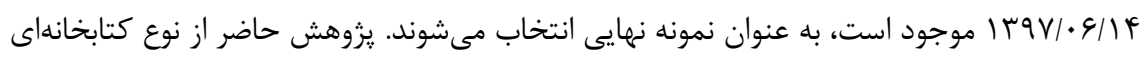

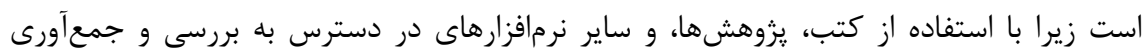

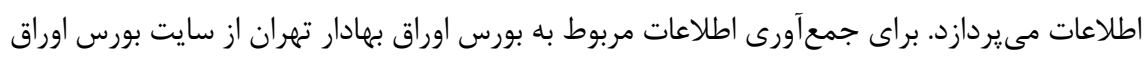
بهادار'، كدال'، و نرمافزار رهآورد نوين استفاده مىشود و براى جمعآورى اطلاعات متغيرهاى كلان

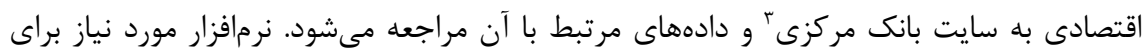

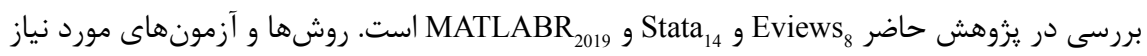
براى رسيدن به هدف اصلى يزوهش معيار ريزش مورد انتظار نهايى است. معيار ريزش مورد انتظار

\section{1. http://www.tsetmc.com}

|rI 
نهايى براى اندازهكيرى سهم بانك در ريسك سيستمى كل نظام مالى يا بانكى موجود مورد استفاده

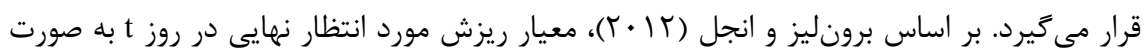
رابطه (1) تعريف مى شود:

$\operatorname{MES}_{i, t}(C)=E_{t-1}\left[R_{i, t} \mid R_{m, t}<C\right]$

كه در آن Rm,t و Ri,t بهتر تيب بازدهى هاى روزانه بازار مالى (مثل بازدهى روزانه شاخص سهام)

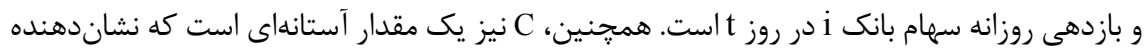

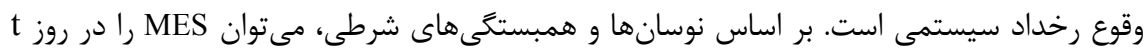

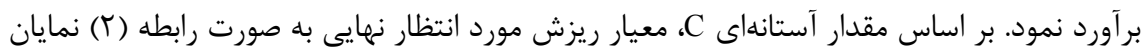

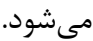

$$
\begin{array}{r}
\operatorname{MES}_{i, t}(C)=E_{t-1}\left[R_{i, t} \mid R_{m, t}<C\right] \\
\operatorname{MES}_{i, t}(C)=\mu_{i, t}+\sigma_{i, t} E_{t-1}\left[\rho_{i, t} \epsilon_{m, t}+\sqrt{1-\rho_{i, t}^{2}} \eta_{i, t} \mid \epsilon_{m, t}<\frac{C-\mu_{m, t}}{\sigma_{m, t}}\right] \\
M E S_{i, t}(C)=\mu_{i, t}+\sigma_{i, t} \rho_{i, t} E_{t-1}\left[\epsilon_{m, t} \mid \epsilon_{m, t}<\frac{C-\mu_{m, t}}{\sigma_{m, t}}\right]+\sigma_{i, t} \sqrt{1-\rho_{i, t}^{2}} E_{t-1}\left[\eta_{i, t} \mid \epsilon_{m, t}<\right. \\
\left.\frac{C-\mu_{m, t}}{\sigma_{m, t}}\right] \\
M E S_{i, t}(C)=\mu_{i, t}+\sigma_{i, t} \rho_{i, t} E_{t-1}\left[\epsilon_{m, t} \mid \epsilon_{m, t}<\frac{C-\mu_{m, t}}{\sigma_{m, t}}\right]
\end{array}
$$

با توجه به اين كه qi,t و ع m,t نسبت به يكديكر مستقل هستند، نتيجه بالا برقرار است. همانطور

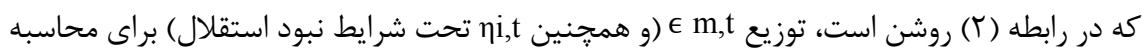

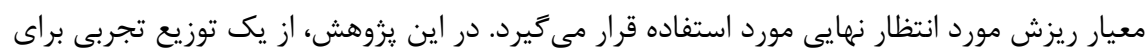
دمهاى يهن مشاهدهده در بازدهى سهام استفاده مىشود. به عبارت ديخر، برآورد مدل DCC بهدست مى آيد. در نتيجه، با استفاده از

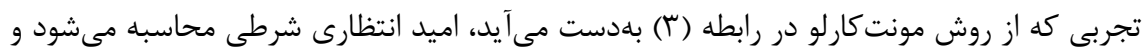

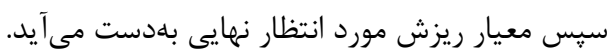

$E_{t-1}\left[\epsilon_{m, t} \mid \epsilon_{m, t}<\frac{C-\mu_{m, t}}{\sigma_{m, t}}\right] \approx \frac{1}{T} \sum_{t=1}^{T} \hat{\epsilon}_{m, t} I\left[\hat{\epsilon}_{m, t}<\frac{C-\mu_{m, t}}{\sigma_{m, t}}\right]$ 
در رابطه (ז)، [.][ يك تابع شاخص است كه اتر عبارت داخل آن صحيح باشد، مقدار يك و در غير اين صورت مقدار صفر به خود مى گيرد.

\section{تجزيدوتحليل يافتهها}

در اين يزوهش، ابتدا با استفاده از دادهایى قيمت تعديلشده سهام ها بانك مورد بررسى،

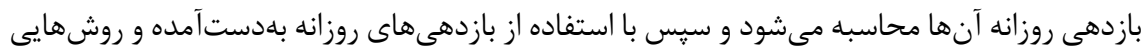
كه در بخش روششناسى بيان شد، ريسك سيستمى هر بانك بر اساس معيار ريزش مورد انتظار نهايى مورد محاسبه قرار مى گيرد. نتيجه محاسبهها به صورت سرى زمانى از ريسك سيستمى هر هر

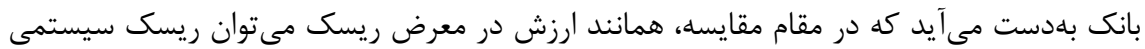
را براى هر روز تحليل و تفسير كرد. سيس براى بررسى عوامل موثر بر ريسك سيستمى بانكها، تحليل هاى همبستكى و ركرسيونى بين شاخصهاى محاسباهده و يكسرى از متغيرهاى ذاتى بانكها

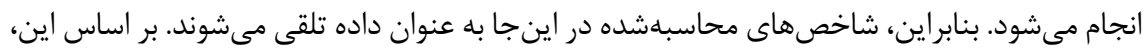
متغيرهاى اين يزوهش كه شامل متغيرهاى محاسباتى و متغيرهاى گردآورىشده هستند، به شرح جدول ( (1) است كه در ادامه توضيح كوتاهى از هر كدام ارائه مىشود.

جدول ا: نوع متغيرهاى مورد استفاده

\begin{tabular}{|c|c|c|}
\hline نحوه محاسبه & نوع متغير & نام متغير \\
\hline زيان مورد انتظار & محاسباتى & معيار ريزش مورد انتظار نهايى \\
\hline بيشترين زيان مورد انتظار & محاسباتى & ارزش در معرض ريسك \\
\hline تعداد سهام × قيمت بازارى سهام & كردآورى & ارزش بازارى \\
\hline ارزش دفترى دارايىهاى بانك & 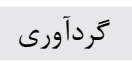 & حجم دارايىها \\
\hline بدهى/ حقوق صاحبان سهام & 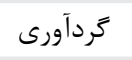 & 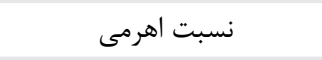 \\
\hline 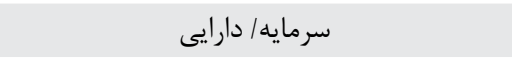 & 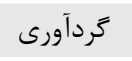 & 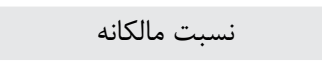 \\
\hline رشد نقطه به نقطه شاخص قيمتها در هر فصل & 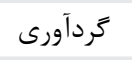 & تورم \\
\hline رشد توليد ناخالص داخلى در هر فصل & 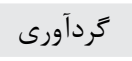 & 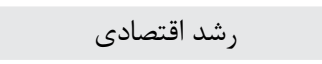 \\
\hline نرخ ارز حقيقى & 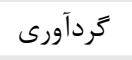 & 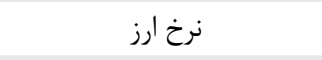 \\
\hline حجم نقدينكى اقتصاد & 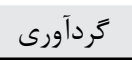 & نقدينكى \\
\hline
\end{tabular}


در اين يزوهش با بهره مبتنى بر ريسك سيستمى معيار ريزش مورد انتظار نهايى براى تعداد ها بانك كشور در دوره

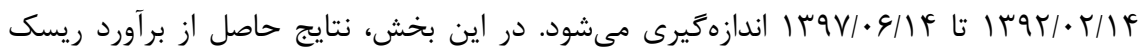
سيستمى و سهم هر بانك در ميزان ريسك سيستمى نظام بانكى در هر دو بُعد سرى زمانى و مقطع

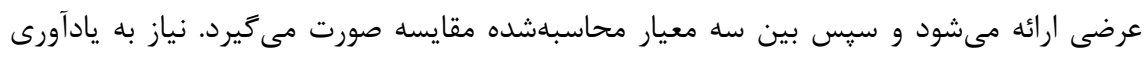

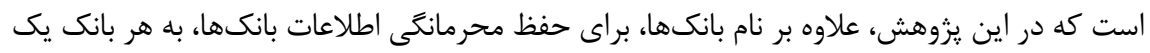
شماره داده مىشود.

ارزش در معرض ريسك و سنجش ريسك سيستمى

ارزش در معرض ريسك به عنوان يكى از متغيرهاى اصلى محاسبة ريسك سيستمى است. از

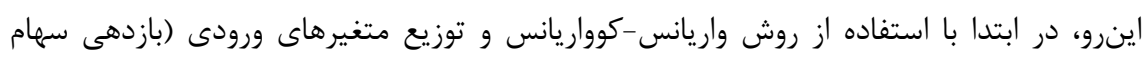

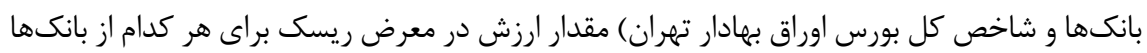

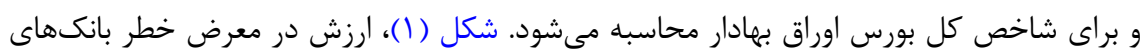
مختلف را در دوره مورد بررسى نشان مى دهد.

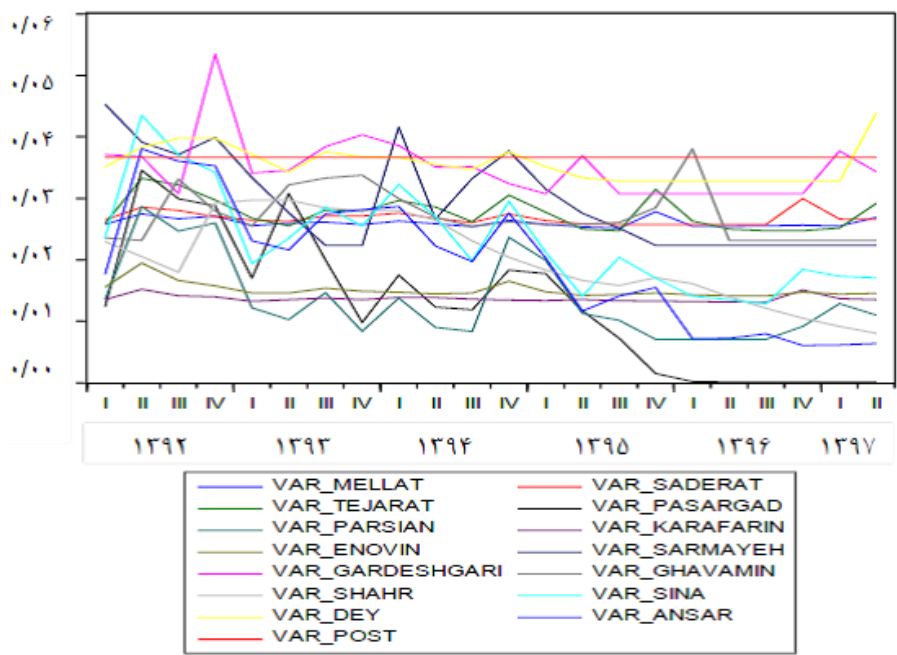

شكل 1: ارزش در معرض ريسك بانككها 
همان كونه كه مشاهده مىشود، ارزش در معرض ريسك بانك ها كه در اين جا ميانكَين فصلى آنها

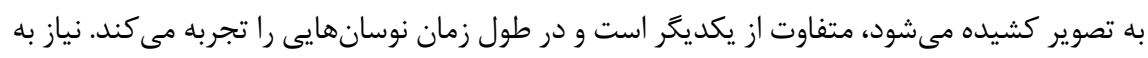

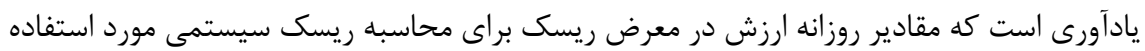

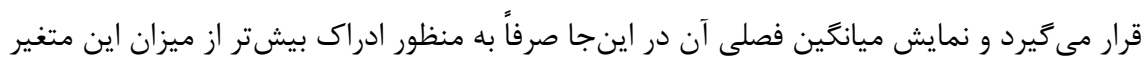

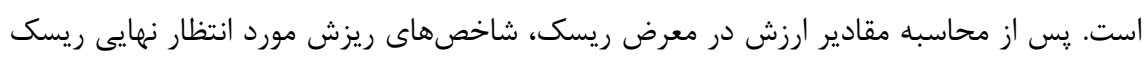
سيستمى محاسبه و در ادامه نتايج ارائه مىشود (شكل ب ك).

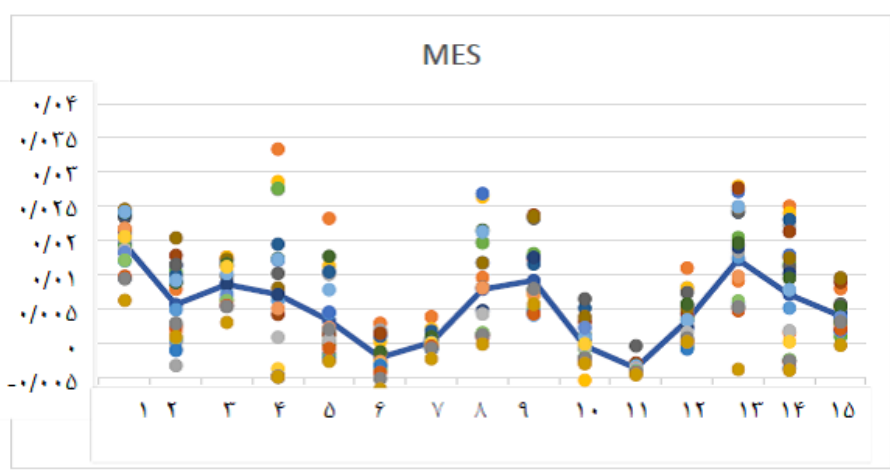

شكل r: ريسك سيستمى محاسبهشده بر مبناى معيار ريزش مورد انتظار نهايى براى ها بانكى در دوره 1rar-1rar نكته: اعداد ا تا ها نشاندهنده شماره بانك هستند.

شكل (Y)، همخنى ريسك سيستمى معيار ريزش مورد انتظار نهايى را بين بانكها نشان مى دهد

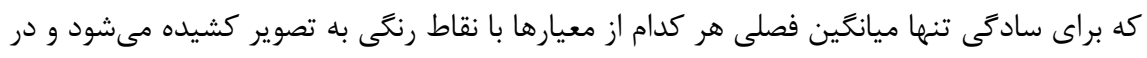

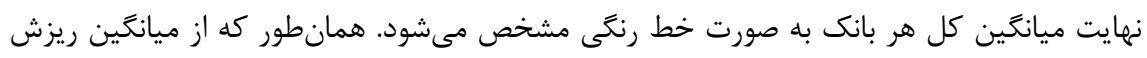

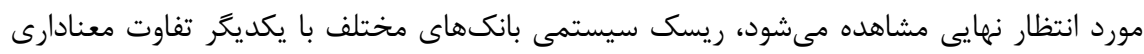

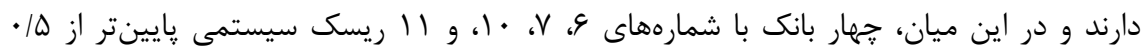

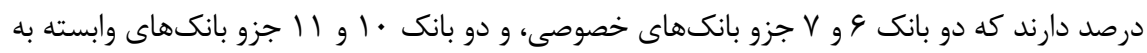

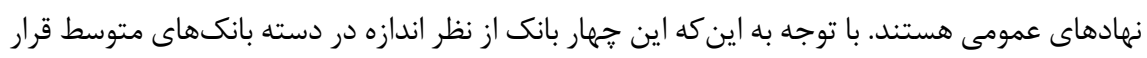

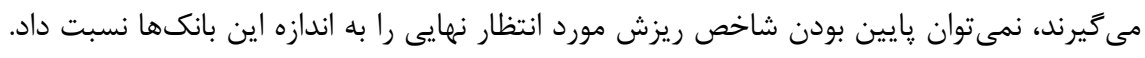

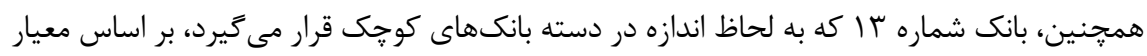


ريزش مورد انتظار نهايى ريسك سيستمى بزرگى دارد. بر اساس تعريفى كه از ريزش مورد انتظار نهايى انجام مىشود، در شرايطى كه كل بازار بورس اوراق بهادار تهران شرايط بحرانى (افت بيشتر لتر از

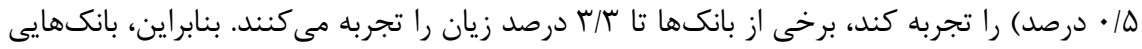

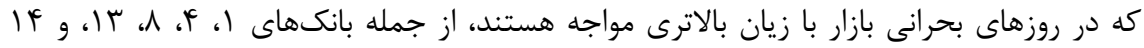
بيشترين ريسك سيستمى را در بين بانكهاى مورد بررسى دارند. در نتيجه، اين بانكها به صورت بهري بالقوه مستعد تاثيريذيرى از زيان سيستم در شرايط بحرانى هستند و نهاد نظارتى (بانك مركزى) بايد توجه ويزهاى بر اين بانكها داشته باشد.

جدول ז: هنج بانك با بيشترين ريسك سيستمى بر اساس معيار ريزش مورد انتظار نهايى

\begin{tabular}{|c|c|c|c|c|c|}
\hline سيزان ريستمى & اندازه & نوع مالكيت بانك & حيطه فعاليت & نام بانك & شماره بانك \\
\hline .1 .19 & بزرى & خصوصىسازى شده & تجارى غيردولتى & بانك ملت & بانك 1 \\
\hline.$/ \cdot 1 \mathrm{~V}$ & كوجى & وابسته به نهادهاى عمومى & تجارى غيردولتى & بانك دى & بانك זו \\
\hline $.1 \cdot 14$ & كوجى & خصوصى & تجارى غيردولتى & بانك َردشگرى & بانك 9 \\
\hline$\cdot / \cdot 14$ & بزرى & خصوصىسازى شده & تجارى غيردولتى & بانك تجارت & بانك r \\
\hline.$/ \cdot 14$ & متوسط & خصوصى & تجارى غيردولتى & بانك سرمايه & بانك 1 \\
\hline
\end{tabular}

از بين بانكهاى جدول (T) كه بيشترين ميزان ريسك سيستمى را در بين ها بانك مورد بررسى

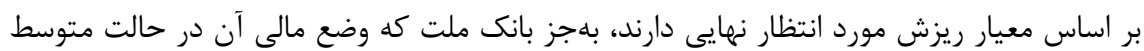

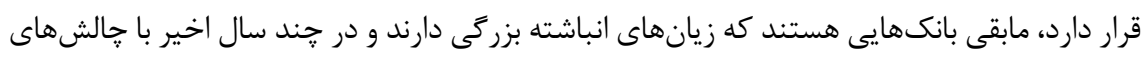

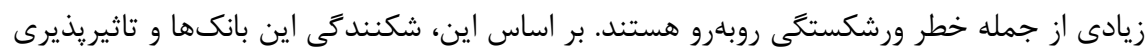
آنها از شرايط بحرانى در بازار مالى ممكن است به بحران بانكى و هجوم بانكى منجر شود، كه توجه

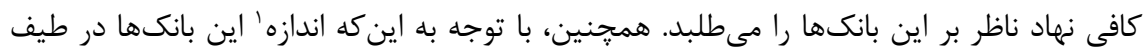

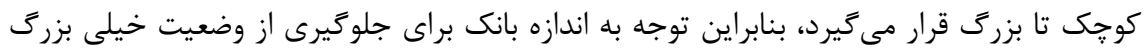

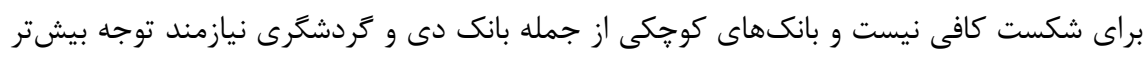
ا. اندازه شركت از لكاريتم دارايىهاى شركت بهدست مى آيد و شركتهايى كه للعاريتم دارايىهاى آن از

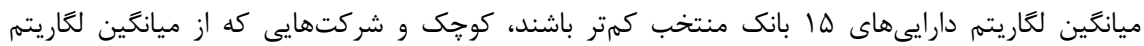

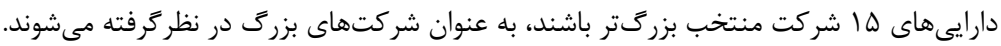


نهاد ناظر از جمله تعيين الزامات كفايت سرمايداى و سازماندهى وضعيت مالى آنهاست.

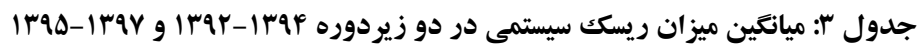

\begin{tabular}{|c|c|c|}
\hline زيردوره Vqس||-Mqه & زيردوره & \\
\hline •/ . TVAGDSA &.$/ \cdot I Y \wedge \vee \Lambda \cdot .9$ & ميانغين MES \\
\hline
\end{tabular}

كاهش ميزان ريسك سيستمى در زيردوره دوم (جدول ؟) به عوامل متعددى بستخى دارد. كاهش نوسانهاى ارزى، كاهش تورم، و بهبود رشد اقتصادى در اين زيردوره از جمله عواملى هستند كه بر بر برد

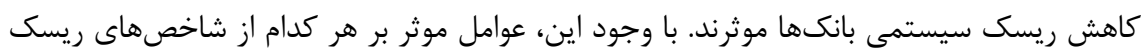

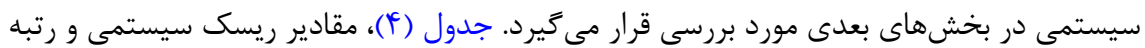

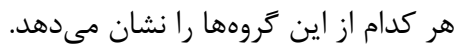

جدول ^: ميزان ريسك سيستمى بلندمدت كروه بانكها و رتبه آنها

\begin{tabular}{|c|c|c|}
\hline رتبه & ريزش مورد انتظار نهايى & 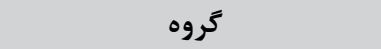 \\
\hline 1 & $.1 \cdot 1 \mathrm{FV}$ & بانكهاى خصوصىشده \\
\hline$r$ & $.1 \cdot 94$ & بانكهاى خصوصى \\
\hline f & $\cdot / \cdot \wedge \varepsilon$ & بانكهاى وابسته به نهادهاى عمومى \\
\hline$r$ & $.1 \cdot 9$. & بانكهاى وابسته به دولتى \\
\hline
\end{tabular}

تخمين عوامل موثر بر ريسك سيستمى با استفاده از تحليل ركرسيون پانل

براى بررسى دقيقتر عوامل موثر بر معيارهاى ريسك سيستمى مدلهاى اقتصادسنجى پانلى

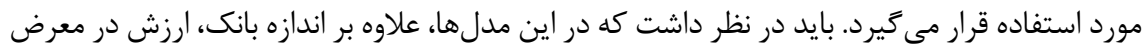
ريسك و ارزش بازارى، احتمال تاثيرگذارى برخى ديگر از مشخصههاى ذاتى بانك از جمله نسبت

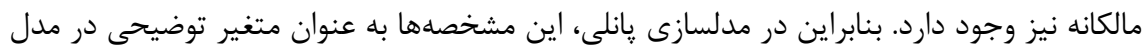

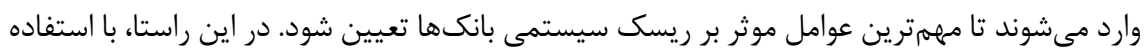

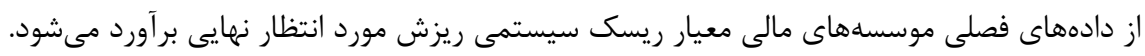


همجنين، براى جلوگيرى از ايجاد مشكل احتمالى درونزايى، متغيرهاى توضيحى با يك وقفه فصلى

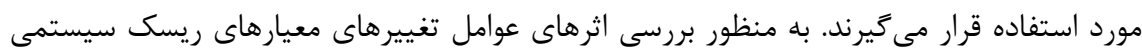
در طول زمان و در بين بانكها، علاوه بر اين كه متغيرهاى ذاتى بانكها به عنوان متغيرهاى توضيحى

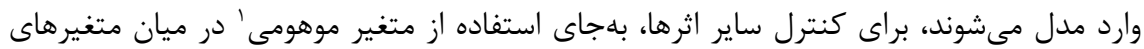

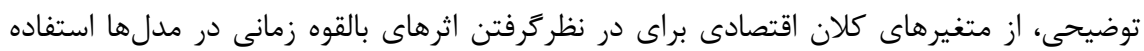

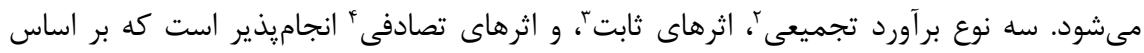

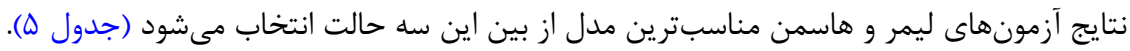

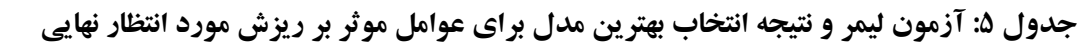

\begin{tabular}{lllll}
\hline آزمون ليمر & آماره \\
\hline
\end{tabular}

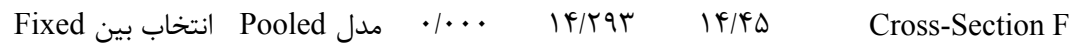

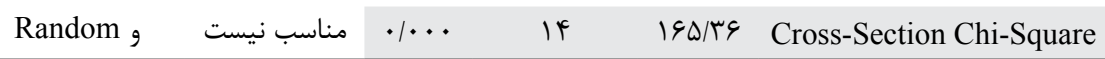

از جدول آزمون ليمر، آماره F بهدستآمده برابر با ه\&/F/ أست كه احتمال متناظر با آن كه به معناى احتمال يذيرفتن فرضيه صفر است، معادل صفر است. بنابراين، فرضيه H0 مبنى بر بر مساوى لماره

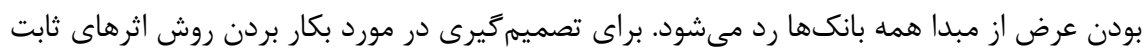

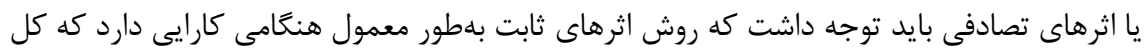

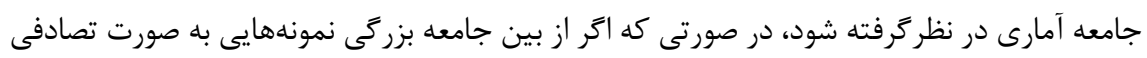

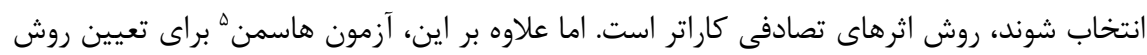

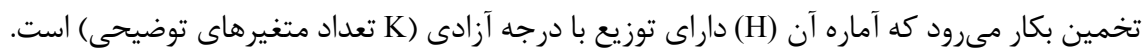

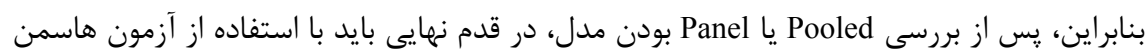

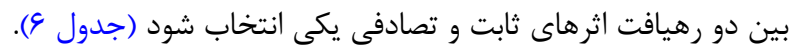

2. Pooled

3. Fixed Effect

4. Random Effect

5. Hausman 
جدول و: آزمون هاسمن و نتيجه انتخاب بهترين مدل براى عوامل موثر بر ريزش مورد انتظار نهايى

\begin{tabular}{ccccc}
\hline آزمون هاسمن & آماره & Cross-Section \\
Random
\end{tabular}

با توجه به اين كه يك فرض اساسى در مدل اثرهاى تصادفى، مستقل بودن اثرهاى فردى از

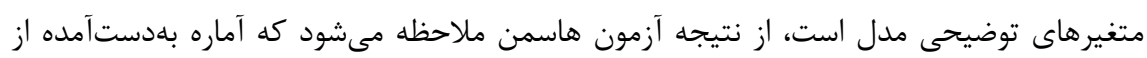

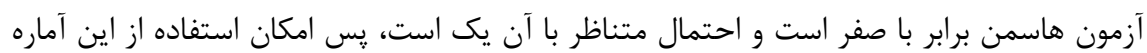

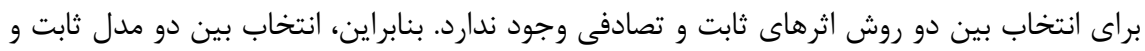

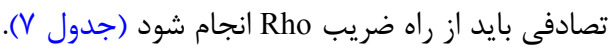

جدول Y: نتايج ضريب Rho در بر آورد مدل اثرهاى تصادفى عوامل موثر بر ريزش مورد انتظار نهايى

\begin{tabular}{|c|c|c|c|}
\hline نتيجه & Rho ضريب Rho & انحراف معيار & \\
\hline \multirow{2}{*}{ روش اثرهاى ثابت مدل مناسبترى است } & . T\&צq & $\cdot 1 \cdot r \cdot r$ & Cross-Section Random \\
\hline & . $|9 \mathrm{TV}|$ & $\cdot|\cdots+9 \wedge|$ & Idiosyncratic Random \\
\hline
\end{tabular}

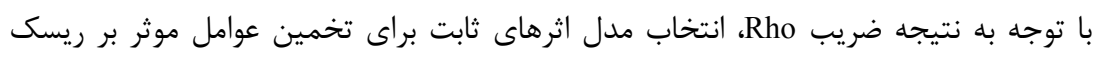
سيستمى مبتنى بر معيار ريزش مورد انتظار نهايى نتايج مناسبترى را به همراه دارد. بنابراين، بهطور

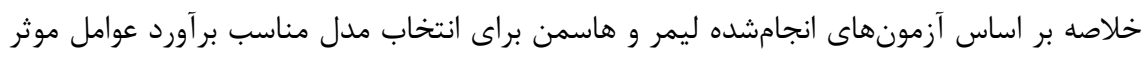
بر شاخصهاى ريسك سيستمى، مشخص مىشود كه براى معيار ريزش مورد انتظار نهايى روش

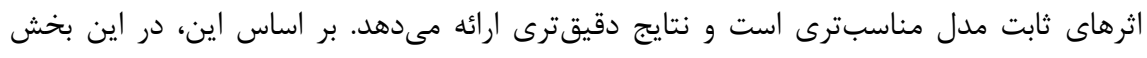

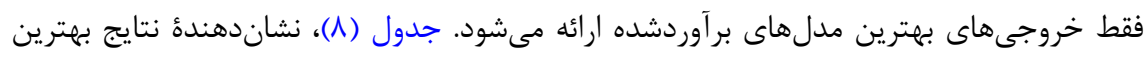
مدلهاى حاصل از برآورد عوامل موثر بر شاخص ريسك سيستمى است. 


\begin{tabular}{|c|c|c|}
\hline & روش اثرهاى ثابت & روش \\
\hline & ريزش مورد انتظار نهايى & معيار \\
\hline احتمال & ضريب & متغير \\
\hline$\cdot / 48$ & $-\cdot \cdot \cdot$ tgF & $\mathrm{C}$ \\
\hline$\cdot / \cdot$ & $\cdot / r q \cdot v$ & ارزش در معرض ريسك \\
\hline$\cdot / \cdot$ & $-\cdot \cdot \cdot r v$ & لكاريته ارزش دارايىها \\
\hline$\cdot 1 \cdot$ & • & لحاريتم ارزش بازارى سهام \\
\hline$\cdot / 4 q$ & $\cdot / \cdots$ & نسبت اهرمى \\
\hline$\cdot / \cdot$ &.$/ \cdot 1 r$. & نسبت مالكانه \\
\hline$\cdot 1 \cdot$ & $\cdot 1 \cdot r q$ & تو تورم \\
\hline$\cdot / \cdot$ & $-\cdot / \cdot \cdot V V$ & ر رشد اقتصادى \\
\hline$\cdot 1 \cdot$ & $\cdot / \cdot I \Delta T$ & نرخ ارز \\
\hline \multirow[t]{5}{*}{$\cdot / \cdot$} & $\cdot / K I Q F$ & نقدينكى \\
\hline & $\% \vee r$ & $\mathrm{R}^{2}$ \\
\hline & $\% \vee 1$ & Rع تعديلشده \\
\hline & एद/q६ & F آماره F \\
\hline & $\cdot 1 \cdots$ & احتمال \\
\hline
\end{tabular}

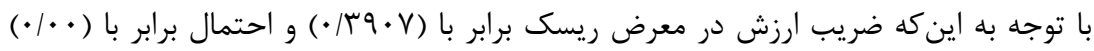

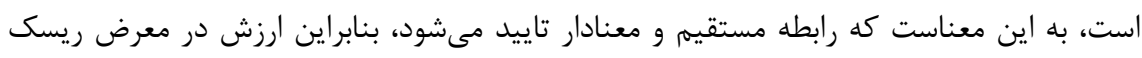

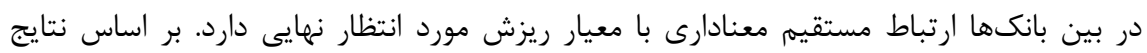

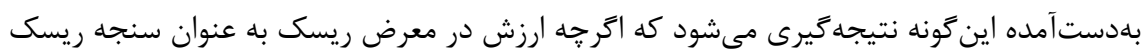

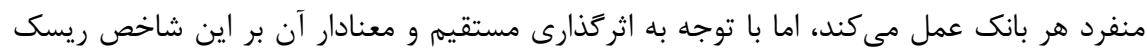

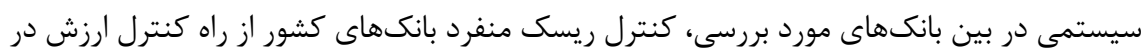
معرض ريسك مى مواند موجب كنترل ريسك سيستمى شود. 
تخمين عوامل موثر بر شاخصهاى ريسك سيستمى با مدلهاى GMM

علاوه بر مدلهاى پانل در حالت ايستا، تخمين آن به صورت يويا مىتواند پِايدارى نتايج را نشان دهد. بر اساس اين، براى ريسك سيستمى محاسبهشده، مدلهاى گشتاور تعميميافته

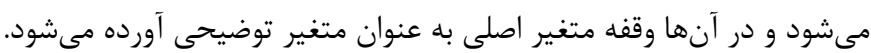

جدول ج: تخمين اثر عوامل موثر بر شاخصهاى ريسك سيستمى با مدلهاى GMM

\begin{tabular}{|c|c|c|}
\hline \multicolumn{3}{|c|}{ ريزش مورد انتظار نهايى } \\
\hline احتمال & ضريب & متغير \\
\hline$\cdot /$ & ./FTI91 & ريزش مورد انتظار نهايى (1-) \\
\hline$\cdot / \cdot$ & $-\cdot / \cdot q \cdot \operatorname{kr}$ & $\mathrm{C}$ \\
\hline$\cdot / \cdot$ & - /FFFqR & ارزش در معرض ريسك \\
\hline.$/ 94$ & $-\cdot / \cdot \cdots r$ & لمَاريتم ارزش دارايىها \\
\hline$\cdot / \cdots$ & $\cdot / \cdot r \wedge F$ & لكاريتم ارزش بازارى سهام \\
\hline$\cdot 1 \cdot r$ & $-\cdot 1 \cdot \cdots \cdot \Delta$ & ن نسبت اهرمى \\
\hline$\cdot / 49$ & $-\cdot / \cdot r \Delta r$ & نسبت مالكانه \\
\hline$\cdot / \cdot \Delta$ & $\cdot 1 \cdot \cdot 9 \cdot 9$ & 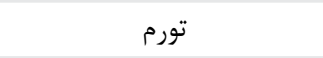 \\
\hline$\cdot / \cdot r$ & $-\cdot / \cdot 1 \cdot r$. & ر رشد اقتصادى \\
\hline$\cdot 1 \cdot 1$ & $\cdot / \cdot F \mid r \Delta$ & 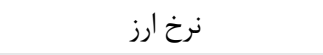 \\
\hline \multirow[t]{3}{*}{$\cdot / \cdot$} & $\cdot 1 \cdot \Delta \wedge q f$ & نقدينكى \\
\hline & $\% .9 \Lambda$ & $\mathrm{R}^{2}$ \\
\hline & $\% q V$ & R2 تعديلشده \\
\hline
\end{tabular}

بر اساس جدول (9)، با توجه به اين كه وقفه متغير وابسته در مدل وارد مىشود، و ضريب و احتمال

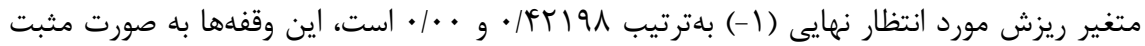
و معنادار بر معيار ريسك سيستمى اثركذار هستند. بدين صورت كه در ازاى يك واحد درصد افزايش

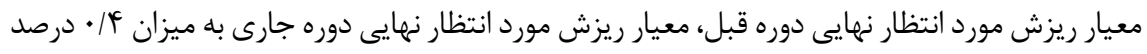
افزايش مىيابد. در روش تخمين مدلها به روش GMM ارزش در معرض ريسك اثر مستقيم و معنادارى مورد 
بر معيار ريزش مورد انتظار نهايى دارد. بنابراين، ارزش در معرض ريسك رابطه مستقيم و معنادارى

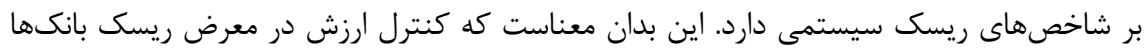
مى تواند موجب كنترل ريسك سيستمى آنها شود. با توجه به نتايج تخمين مدلهاى يانل و نتايج تخمين مدلهاى GMM براى اثر خذارى ارزش در معرض ريسك بر شاخصهاى ريسك سيستمى، و با توجه اين كه ارزش در معرض ريسك به عنوان يكى از اصلىترين شاخصهاى ريسك منفرد بانكهاست،

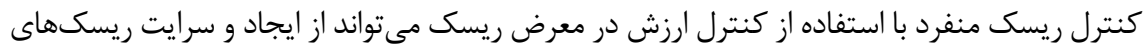

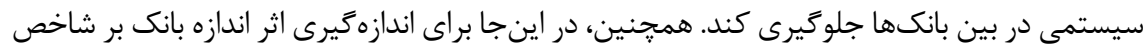

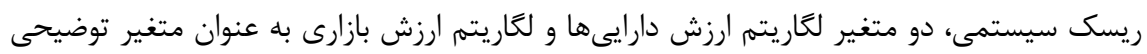

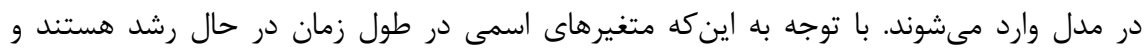
ارزش دارايى هاى بانكها به تناسب رشد متغيرهاى اسمى افزايش مىيابد، بنابراين بهتنهايى نمىتواند

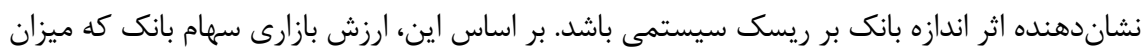

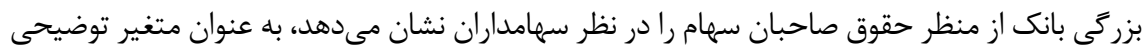

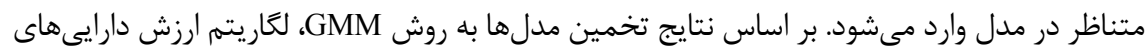

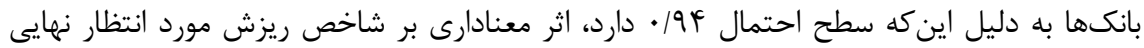

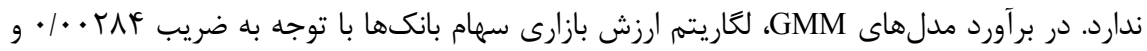

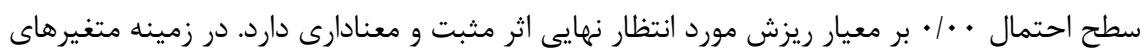

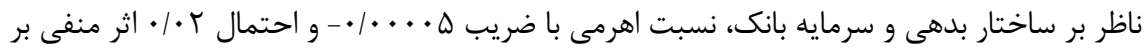
شاخص ريسك سيستمى دارد. اين نتايج نشان مى دهد بانكهايى كه نسبت بدهى به حقوق صاحبان بـان

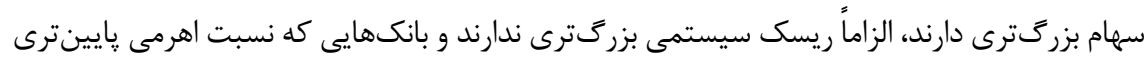

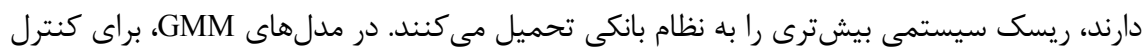
اثرهاى شرايط كلان اقتصادى نيز دو متغير رشد اقتصادى و نرخ تورم به عنوان مهممترين متغيرهاى كلان اقتصادى اثر گذار بر ريسك سيستمى بانكها در مدلها كنجانده ميىشود. بر اساس نتايج بهدست آمده،

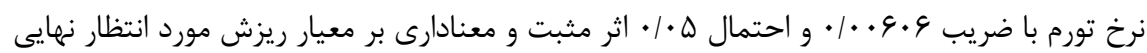

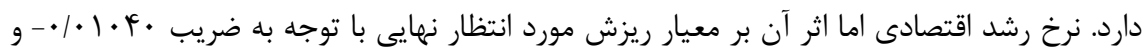

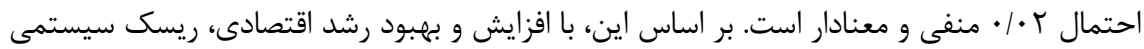

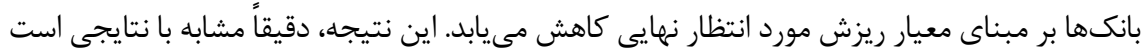
كه در تخمين گپانل از رشد اقتصادى بلهدست آمد. 


\section{شاخص تجميعى ريسك سيستمى}

يكى از مزيتهاى معيار ريزش مورد انتظار نهايى خاصيت جمعيذير بودن آن روى بانكهاست كه مى تواند در ساختن يك شاخص تجميعى براى ريسك سيستمى كل نظام بانكى مورد استفاده قرار كيرد.

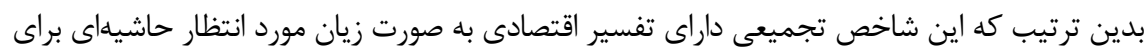
يرتفويى از سهام بانكهاست، تحت شرايطى كه بازدهى بازار در يايينتر از سطح آستانهاى تعيينشدهاى

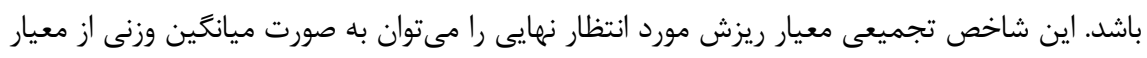

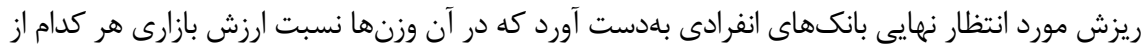

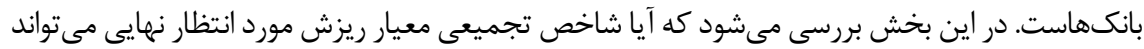

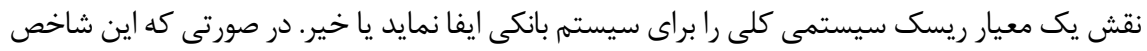

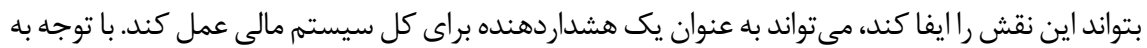
اين كه بسيارى از تصميمهاى سياستى، مانند سياستهاى نرخ خذارى بانك مركزى، به صورت ماهانه ايجاد

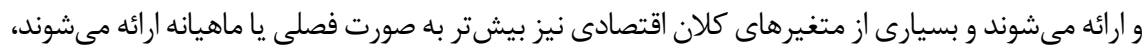
بنابر اين مناسب است كه شاخصى كه براى ريسك سيستمى تجميعى محاسبه مىشود، به صورت ماهانه

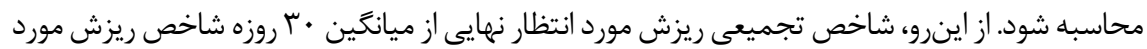

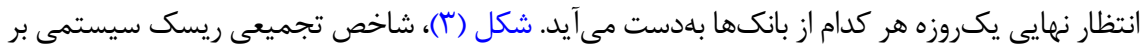

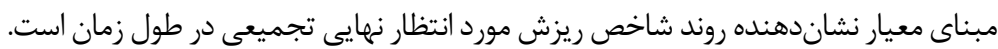

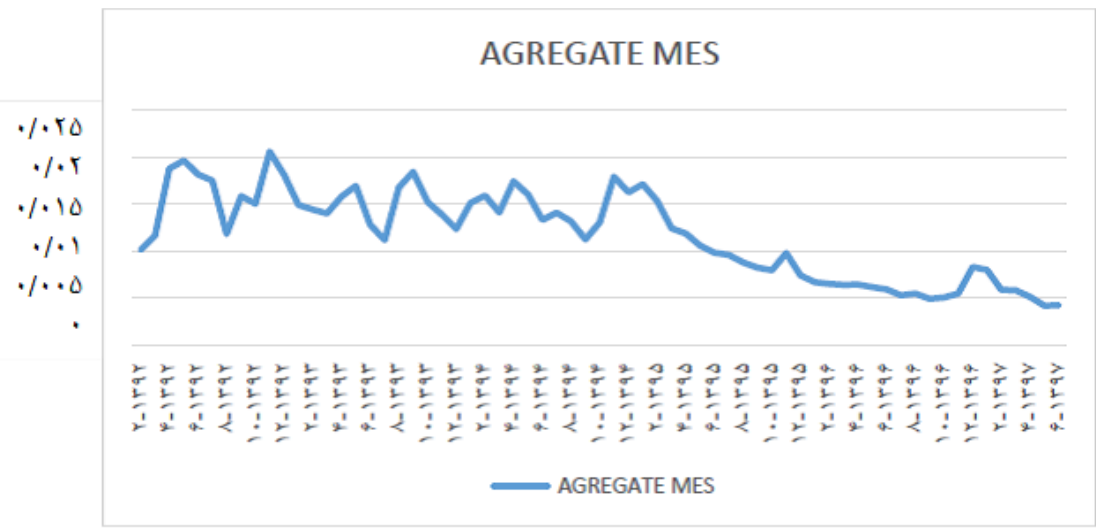


بر اساس معيار ريزش مورد انتظار نهايى تجميعى در شكل (r) مشاهده مىشود كه از ابتداى

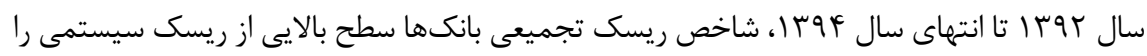

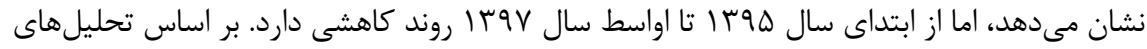
ركرسيونى، از جمله عواملى كه در روند نزولى معيار ريزش مورد انتظار نهايى در بين دو زيردوره موثر است، كاهش ارزش در معرض ريسك بانكها، بهبود رشد اقتصادى، كاهش نرخ تورم، نوسانهاى نرخ ارز، و كاهش رشد نقدينكى است. دومين عامل ريسك سيستميك كه ريسك شبكه ناميده مىشود، ناشى از يكيارجگىى زياد و ارتباطهاى درهمتنيده سيستمهاى مالى در قراردادها، اطلاعات، و رفتار

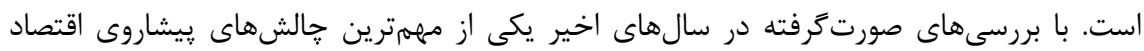

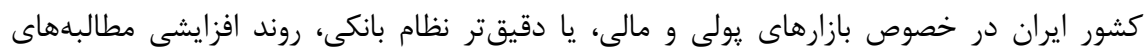
سررسيد كذشته و حتى معوقههاست، كه عارضهاى بدخيم است و نهتنها براى نظام بانكى كشور

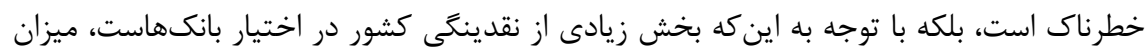

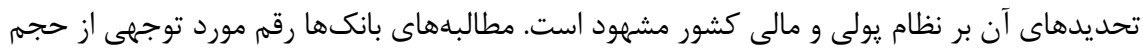

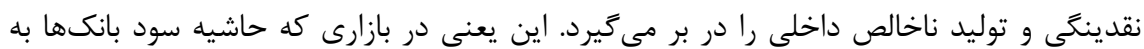
دليل تشديد رقابت همواره در حال كاهش است، فشار بر كاهش بيشتر هزينهها محسوس مىشود.

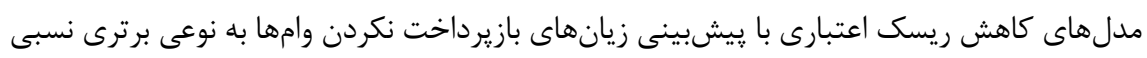
براى بانكها و نهادهاى اعتبارى ايجاد مي كند.

\section{بحث و نتيجه}

ريسك سيستميك به عنوان عاملى كه مىتواند با ايجاد سرايتيذيرى از شركتى به شركت ديخر

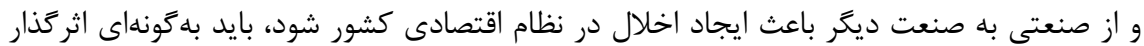

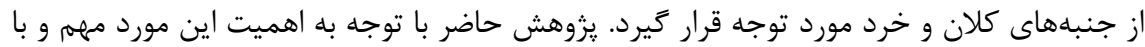

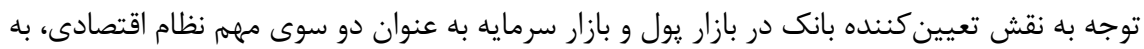
تبيين مدل ريسك سيستميك با استفاده از معيار ريزش مورد انتظار نهايى در بانكهاى يذيرفتهدهد در بورس اوراق بهادار تهران مىيردازد. در اين راستا، ريسك سيستمى از دو جنبه كلان و خرد در بانكها مورد توجه قرار مى كيرد. نتايج نشان مى دهد كه ارزش در معرض ريسك بين بانكها مورد ارتباط مستقيم معنادارى با معيار

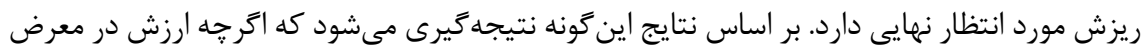


ريسك به عنوان سنجه ريسك منفرد هر بانك عمل مى كند، اما با توجه به اثر گذارى مستقيمم و معنادار آن بر اين شاخص ريسك سيستمى در بين بانكهاى مورد بررسى، كنترل ريسك منفرد بانكىهاى

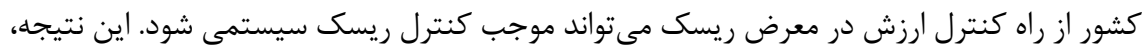

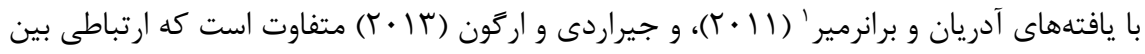
ارزش در معرض ريسك و شاخصهاى ريسك سيستمى بيدا نكردند.

لكَاريتم دارايىهاى بانكها اثر منفى بر معيار ريزش مورد انتظار نهايى دارد. اثر منفى بر معيار

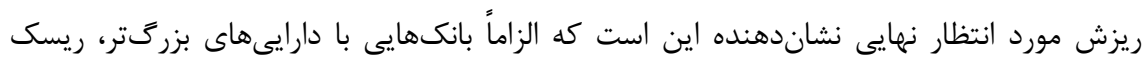

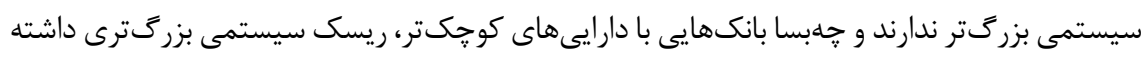

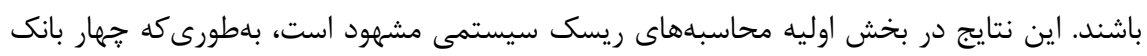

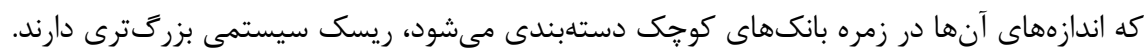

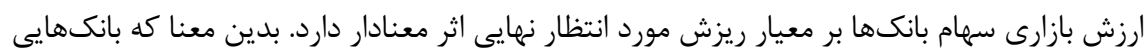
كه ارزش بازارى بزرگترى دارند، ريسك سيستمى بزرى

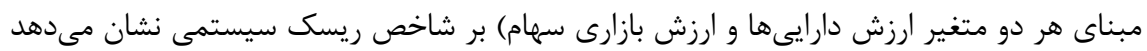

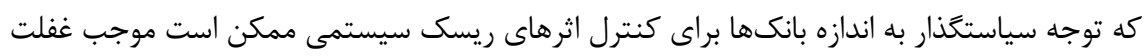

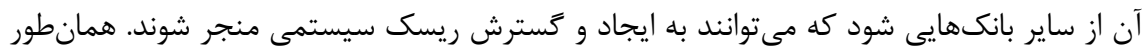

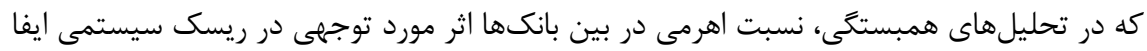

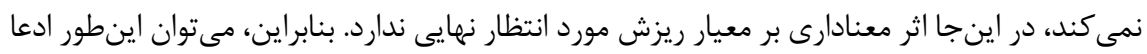
كرد كه جه در بُعد مقطع عرضى و جه در بُعد سرى زمانى، نسبت اهرمى به عنوان نماينده ساختار

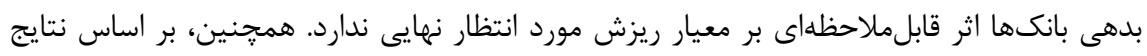

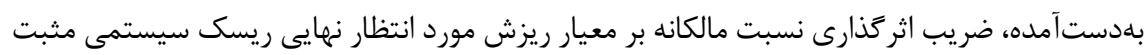

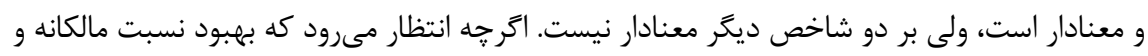

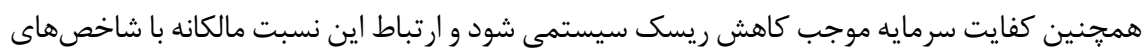
ريسك سيستمى معكوس باشد، اما اينطور بحث مىشود كه نقش اين گونه نسبتها به خاطر ماهيت

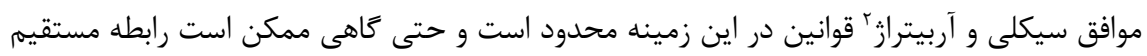

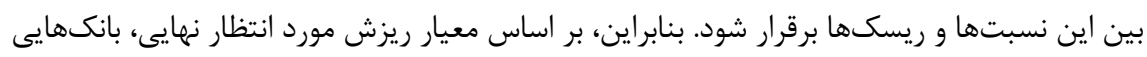


كه نسبت مالكانه بزرگترى دارند، داراى ريسك سيستمى بيشترى نيز هستند.

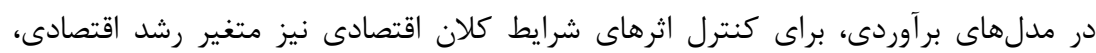

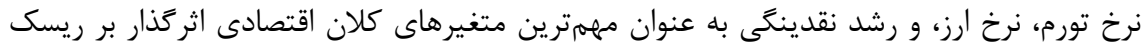

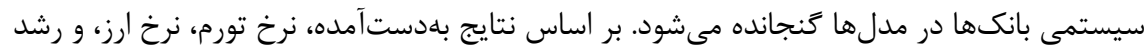

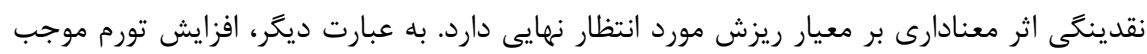

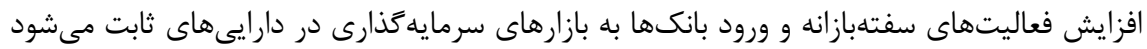
كه نتيجه اين موضوع يرريسك شدن يرتفوى سرمايه گذارى بانكهاست. تحت اين شرايط، تغيير در

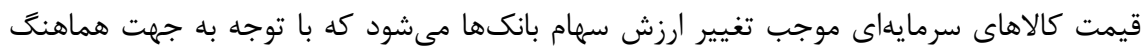

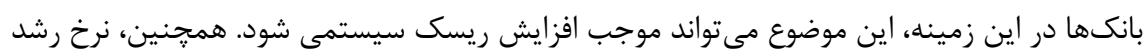

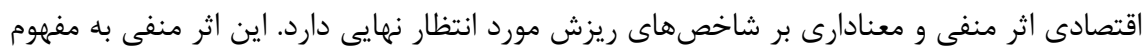

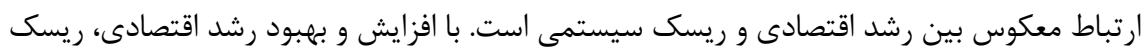

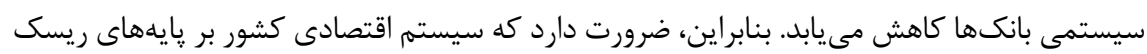

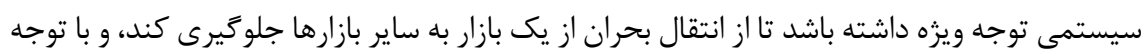

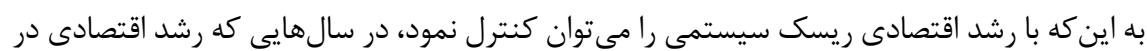

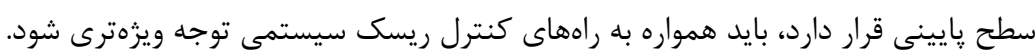

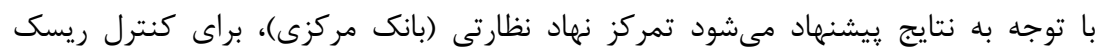
سيستمى از بانكهاى بزرگ به سمت تمام بانكها معطوف شود. با توجه به اينكه در ايران، هنوز

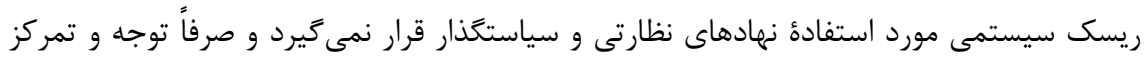

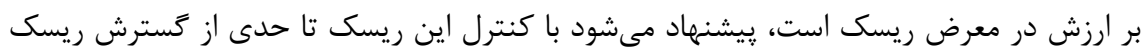

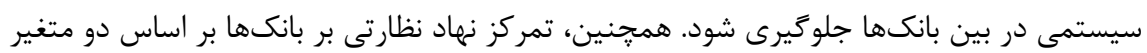
اندازه بانك و اهرم بانك ممكن است موجب غفلت بانك مركزى از برخى بانكهاى داراى اهميت

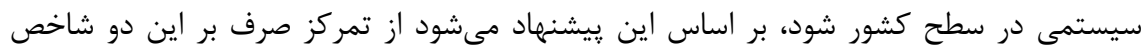
خوددارى شود و سعى در تعيين شاخصهاى ريسك سيستمى با روشهاى موجود درد در ادبيات بانكى

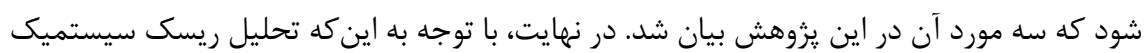

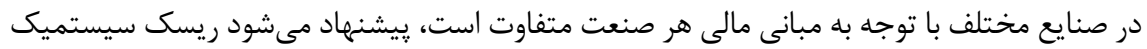

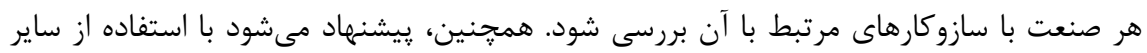
مدلهاى اقتصادسنجى همجون SCoVaR و SRISK ريسك سيستميك مورد تبيين قرار كيرد. 


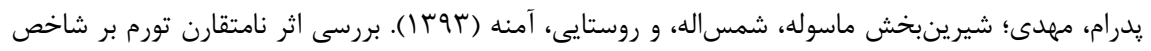

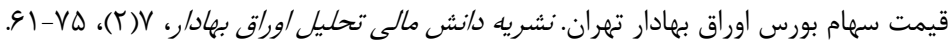

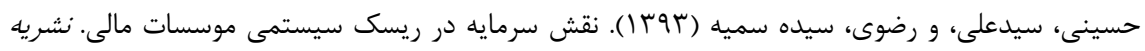

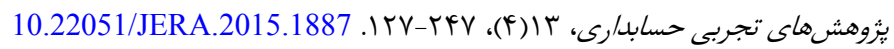

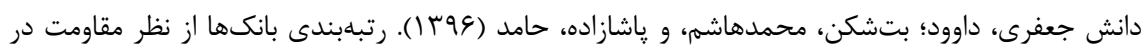

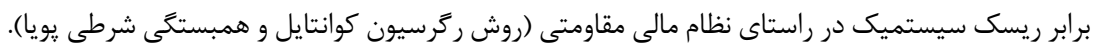

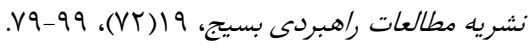

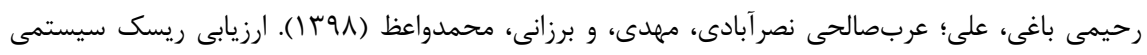

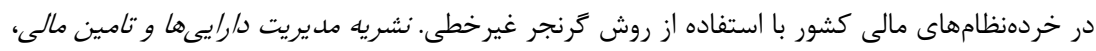

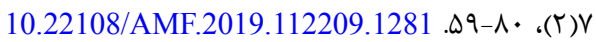

فلاحى، سامان، و رحمانى، تيمور (1) (IVY). شناسايى نقش شوكهاى مالى در نوسانات اقتصاد ايران

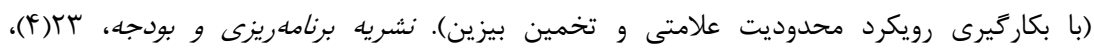
http://jpbud.ir/article-1-1609-fa.html .35-3 مدنى زاده، سيدعلى؛ ابراهيمى، سجاد، و محمودزاده، امينه (צوج (1). حقايقى از روابط بين بنكاه و بانكى: شواهدى از دادههاى

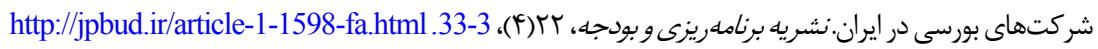

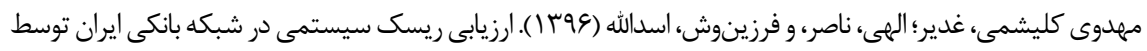

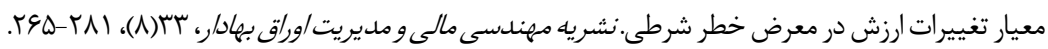

Acharya, V. V., \& Pedersen, L. H. (2005). Asset Pricing with Liquidity Risk. Journal of Financial Economics, 77(2), 375-410. https://doi.org/10.1016/j.jfineco.2004.06.007 Adrian, T., \& Brunnermeier, M. (2011). Co-VaR (Working Paper). Federal Reserve Bank of New York.

Billio, M., Getmansky, M., Lo, A. W., \& Pelizzon, L. (2012). Econometric Measures of Connectedness and Systemic Risk in the Finance and Insurance Sectors. Journal of Financial Economics, 104(3), 535-559. https://doi.org/10.1016/j.jineco.2011.12.010

Boudoukh, J., \& Richardson, M. (1993). Stock Returns and Inflation: A Long-Horizon Perspective. The American Economic Review, 83(5), 1346-1355.

Brownlees, C. T., \& Engle, R. (2012). Volatility, Correlation and Tails for Systemic Risk Measurement. Working Paper. Available at SSRN: http://dx.doi.org/10.2139/ssrn.1611229 
Chen, H., Cummins, J. D., Viswanathan, K. S., \& Weiss, M. A. (2014). Systemic Risk and the Interconnectedness between Banks and Insurers: An Econometric Analysis. Journal of Risk and Insurance, 81(3), 623-652. https://doi.org/10.1111/j.1539-6975.2012.01503.x

De Bandt, O., \& Hartmann, P. (2000). Systemic Risk: A Survey: European Central Bank Working Paper, No. 35.

Derbali, A., \& Hallara, S. (2016). Systemic Risk of European Financial Institutions: Estimation and Ranking By the Marginal Expected Shortfall. Research in International Business and Finance, 37(1), 113-134. https://doi.org/10.1016/j.ribaf.2015.10.013

Flannery, M., Hirtle, B., \& Kovner, A. (2017). Evaluating the Information in the Federal Reserve Stress Tests. Journal of Financial Intermediation, 29(1), 1-18. https://doi.org/10.1016/j.jfi.2016.08.001

Furfine, C. H. (2003). Interbank Exposures: Quantifying the Risk of Contagion. Journal of Money, Credit and Banking, 35(1), 111-128.

Gauthier, C., Lehar, A., \& Souissi, M. (2012). Macroprudential Capital Requirements and Systemic Risk. Journal of Financial Intermediation, 21(4), 594-618. https://doi.org/10.1016/j.jfi.2012.01.005

Girardi, G., \& Ergün, A. T. (2013). Systemic Risk Measurement: Multivariate GARCH Estimation of CoVaR. Journal of Banking \& Finance, 37(8), 3169-3180. https://doi.org/10.1016/j.jbankfin.2013.02.027

Guerra, S. M., Silva, T. C., Tabak, B. M., de Souza Penaloza, R. A., \& de Castro Miranda, R. C. (2016). Systemic Risk Measures. Physica A: Statistical Mechanics and Its Applications, 442(1), 329-342. https://doi.org/10.1016/j.physa.2015.09.013

Hendrich, K. (2012). Copula-Based Analysis of Interdependence among Companies in the Banking and Insurance Sector. Technische Universität München.

Iori, G., Jafarey, S., \& Padilla, F. G. (2006). Systemic Risk on the Interbank Market. Journal of Economic Behavior \& Organization, 61(4), 525-542.https://doi.org/10.1016/j.jebo.2004.07.018

Laeven, L., Ratnovski, L., \& Tong, H. (2016). Bank Size, Capital, and Systemic Risk: Some International Evidence. Journal of Banking \& Finance, 69(1), S25-S34. https://doi.org/10.1016/j.jbankfin.2015.06.022

Poledna, S., Hinteregger, A., \& Thurner, S. (2018). Identifying Systemically Important Companies by Using the Credit Network of an Entire Nation. Entropy, 20(10), 792-806. https://doi.org/10.3390/e20100792

Van den End, J. W. (2010). Liquidity Stress-Tester: A Model for Stress-Testing Banks' Liquidity Risk. CESifo Economic Studies, 56(1), 38-69. https://doi.org/10.1093/cesifo/ifp005

Yin, L., Feng, J., \& Han, L. (2021). Systemic Risk in International Stock Markets: Role of the Oil Market. International Review of Economics \& Finance, 71(1), 592-619. https://doi.org/10.1016/j.iref.2020.09.024

Yun, J., \& Moon, H. (2014). Measuring Systemic Risk in the Korean Banking Sector via Dynamic Conditional Correlation Models. Pacific-Basin Finance Journal, 27(1), 94114. https://doi.org/10.1016/j.pacfin.2014.02.005

Zubair, S., Kabir, R., \& Huang, X. (2020). Does the Financial Crisis Change the Effect of Financing on Investment? Evidence from Private SMEs. Journal of Business Research, 110(1), 456-463. https://doi.org/10.1016/j.jbusres.2020.01.063 